U.S. Gulf Coast Petroleum Systems Project

\title{
Assessment of Undiscovered Continuous Oil and Gas Resources in the Upper Cretaceous Tuscaloosa Marine Shale of the U.S. Gulf Coast, 2018
}

$U_{\text {sing a geology-based assessment methodology, the U.S. Geological Survey assessed mean undiscovered, technically recoverable continuous }}$ resources of 1.5 billion barrels of oil and 4.6 trillion cubic feet of gas in the Upper Cretaceous Tuscaloosa marine shale in onshore and State waters of Louisiana, Mississippi, Alabama, and Florida in the U.S. Gulf Coast region.

\section{Introduction}

The U.S. Geological Survey (USGS) completed a geology-based assessment of undiscovered, technically recoverable oil and gas resources in the continuous, self-sourced reservoir in the Upper Cretaceous Tuscaloosa marine shale of Louisiana, Mississippi, Alabama, and Florida in the U.S. Gulf Coast region (fig. 1). The assessed interval is part of the Upper Jurassic-Cretaceous-Tertiary Composite Total Petroleum System (TPS) in onshore lands and State waters of the U.S. Gulf Coast region. The Tuscaloosa marine shale is an organic-rich, siliceous mudstone of the late Cenomanian to Turonian. Its thickness is as much as $495 \mathrm{feet}(\mathrm{ft})$, and the vertical depths of the reservoirs in currently producing horizontal wells are from 11,000 to $14,000 \mathrm{ft}$.

\section{Geologic Model for Assessment}

The Upper Cretaceous Tuscaloosa Marine Shale Continuous Oil Assessment Unit (AU) is in central Louisiana, southern Mississippi, southern Alabama, and Florida State waters. Its boundaries are defined primarily by thermal maturity, where measured and modeled values from 0.6 to 1.3 percent vitrinite reflectance $\left(\mathrm{R}_{\mathrm{o}}\right)$ indicate that Upper Cretaceous strata are mature for oil generation over a broad area on the paleoshelf and for wet gas and condensate generation on the paleoslope area. The AU boundary in offshore Louisiana, Mississippi, Alabama, and Florida follows the State-Federal water boundary.

For the northern boundary, thermal maturity of 0.6 percent $R_{0}$ is reached at about 9,000-ft subsurface in the Upper Cretaceous regionally, with certain exceptions. Using a gridded surface for depth to the base of the Tuscaloosa marine shale (top of lower Tuscaloosa Formation), the 9,000-ft structural contour generally defined the northern extent of the Tuscaloosa Marine Shale Continuous Oil AU. The northern AU boundary was placed at depths less than $9,000 \mathrm{ft}$ in areas where measured thermal maturity of 0.6 percent $\mathrm{R}_{\mathrm{o}}$ is reached at shallower depths. Thermal maturity models in east Texas (J. Pitman, USGS retired, unpub. data, 2017) and Louisiana (Pitman and Rowan, 2012) provided guidance in western Louisiana where there is limited measured data. In southeastern Mississippi, the northern boundary was placed at depths less than $9,000 \mathrm{ft}$ to account for multiple measured percent $\mathrm{R}_{\mathrm{o}}$ values (including measurements of solid bitumen reflectance) from the Cretaceous, which show that the Upper Cretaceous section is in the oil-generative window (greater than 0.6 percent $\mathrm{R}_{\mathrm{o}}$ ). Further, the heat-flow map by Blackwell and others (2011) showed that southern Mississippi is an area of relatively higher heat flow compared to southern Louisiana and Alabama.

The southern boundary of the Tuscaloosa Marine Shale Continuous Oil AU was delineated where measured and modeled values indicate the thermal maturity of the Tuscaloosa marine shale is less than or equal to 1.3 percent $R_{0}$. The southern boundary of the $A U$ was placed at the 19,000-ft subsurface contour from near Pine Prairie, La., eastward through central Louisiana and was based on measured vitrinite reflectance values from shales in the Tuscaloosa marine shale and in the upper part of the Tuscaloosa Formation. In the Mississippi Bird's Foot delta area
(St. Bernard, Balize, and Plaquemine lobes), low thermal maturity is from recent river avulsion and deposition of a thick package of cold sediment (Rittenour and others, 2007). Low thermal maturity was confirmed by measured percentage of $R_{0}$ values in Tuscaloosa marine shale samples from a well drilled approximately 14 miles east of Hopedale, La., and petrographic and geochemical analysis indicated a thermally immature, undifferentiated Cretaceous section in a well in Mississippi Canyon Block 84 by Wagner and others (1994). These results influenced the divergence of the southern boundary from the 19,000-ft contour in southeastern Louisiana. At the southern margin of the AU in western Louisiana, thermal maturity rises to about 1.3 percent $\mathrm{R}_{\mathrm{o}}$ at about 15,000 - $\mathrm{ft}$ subsurface as interpolated from burial history modeling projected eastward from Texas (Pitman and Rowan, 2012; J. Pitman, USGS retired, unpub. data, 2017). The southeastern AU boundary follows the State-Federal water boundary in offshore Louisiana, Mississippi, Alabama, and Florida.

Subsurface mapping in the Sabine Uplift indicates Cenomanian sediments were not deposited. Placement of the northwestern boundary of the Tuscaloosa Marine Shale Continuous Oil AU near Clare, La., near the Louisiana-Texas State line was influenced by stratigraphic thinning of

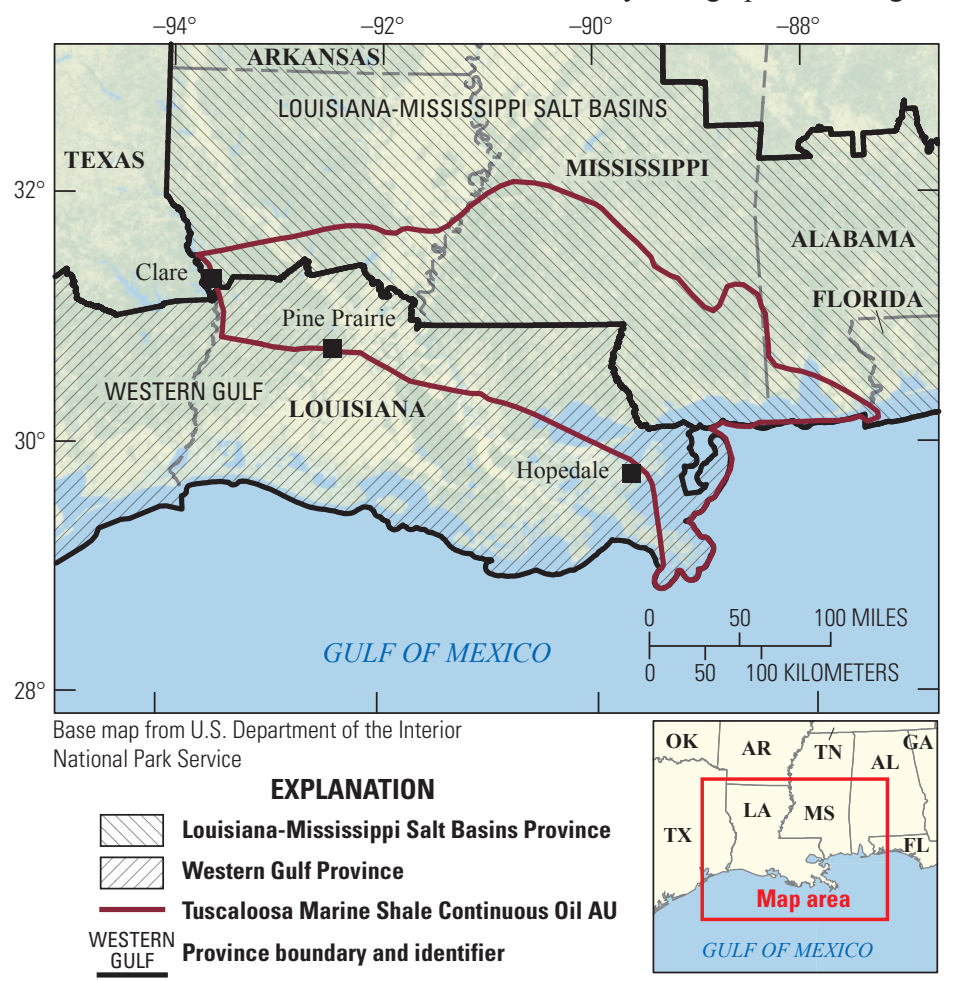

Figure 1. Map showing the Tuscaloosa Marine Shale Continuous Oil Assessment Unit (AU) and related portions of the U.S. Geological Survey-defined Louisiana-Mississippi Salt Basins Province and Western Gulf Province (Klett and others, 1997). 
the Upper Cretaceous section from east and west onto the structural high of the Sabine Uplift as projected downdip. The western boundary of the AU follows the LouisianaTexas State line where the stratigraphic nomenclature changes; the Tuscaloosa Formation is recognized east of this boundary, whereas to the west, correlative strata are included in the Eagle Ford Group (Adams and Carr, 2010)

Self-sourced hydrocarbons in the CenomanianTuronian shale of the Tuscaloosa Marine Shale Continuous Oil AU include black and volatile oils (35-48 American Petroleum Institute [API] gravity) in the shallower, paleoshelf areas where vitrinite reflectance is less than 1.1 percent $\mathrm{R}_{\mathrm{o}}$ and wet gas and condensate (greater than 45 API gravity) in the deeper paleoslope areas where vitrinite reflectance is 1.1 percent $R_{0}$ to about 1.3 percent $R_{0}$.
Table 1. Key input data for one assessment unit (AU) in the Tuscaloosa marine shale of Louisiana, Mississippi, Alabama, and Florida in the U.S. Gulf Coast region.

[AU, assessment unit; \%, percent; EUR, estimated ultimate recovery per well; MMBO, million barrels of oil. Well drainage area, success ratio, and EUR are defined partly using U.S. shale-oil analogs. The average EUR input is the minimum, median, maximum, and calculated mean. Shading indicates not applicable]

\begin{tabular}{|l|c|c|c|c|}
\hline \multirow{2}{*}{\multicolumn{2}{c|}{ Assessment input data }} & \multicolumn{3}{c|}{ Tuscaloosa Marine Shale Continuous Oil AU } \\
\cline { 2 - 5 } & Minimum & Mode & Maximum & $\begin{array}{c}\text { Calculated } \\
\text { mean }\end{array}$ \\
\hline Potential production area of AU (acres) & 1,500 & $1,500,000$ & $20,411,000$ & $7,304,167$ \\
\hline Average drainage area of wells (acres) & 75 & 150 & 185 & 136.7 \\
\hline Untested area (\%) & 90 & 94 & 99 & 94.3 \\
\hline Success ratio (\%) & 5 & 25 & 75 & 35.0 \\
\hline Average EUR (MMBO) & 0.04 & 0.08 & 0.2 & 0.086 \\
\hline AU probability & 1.0 & & & \\
\hline
\end{tabular}

\section{Undiscovered Resources Summary}

The USGS assessed undiscovered, technically recoverable continuous resources in Louisiana, Mississippi, Alabama, and Florida State waters of the U.S. Gulf Coast region (table 2). Assessed mean resources for the Tuscaloosa Marine Shale Continuous Oil AU are 1,537 million barrels of oil (MMBO), or 1.5 billion barrels of oil;
4,614 billion cubic feet of gas (BCFG), or 4.6 trillion cubic feet of gas; and 138 million barrels of natural gas liquids (MMBNGL). For the Tuscaloosa Marine Shale Continuous Oil AU, the assessed oil resources have an F95-F5 range from 181 to 4,215 MMBO, the assessed gas resources have an F95-F5 range from 529 to $12,742 \mathrm{BCFG}$, and the assessed natural gas liquids resources have an F95-F5 range from 15 to 393 MMBNGL.

Table 2. Results for one continuous assessment unit (AU) in the Tuscaloosa marine shale of Louisiana, Mississippi, Alabama, and Florida in the U.S. Gulf Coast region.

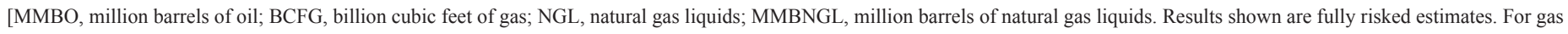

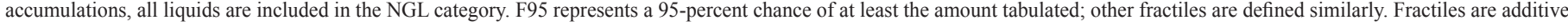
under the assumption of perfect positive correlation. Shading indicates not applicable]

\begin{tabular}{|c|c|c|c|c|c|c|c|c|c|c|c|c|c|c|}
\hline \multirow{3}{*}{$\begin{array}{l}\text { Total petroleum system } \\
\text { and assessment unit (AU) }\end{array}$} & \multirow{3}{*}{$\begin{array}{c}\text { AU } \\
\text { prob- } \\
\text { ability }\end{array}$} & \multirow{3}{*}{$\begin{array}{l}\text { Accumu- } \\
\text { lation } \\
\text { type }\end{array}$} & \multicolumn{12}{|c|}{ Total undiscovered resources } \\
\hline & & & \multicolumn{4}{|c|}{ Oil (MMBO) } & \multicolumn{4}{|c|}{ Gas (BCFG) } & \multicolumn{4}{|c|}{ NGL (MMBNGL) } \\
\hline & & & F95 & F50 & F5 & Mean & F95 & F50 & F5 & Mean & F95 & F50 & F5 & Mean \\
\hline \multicolumn{15}{|c|}{ Upper Jurassic-Cretaceous-Tertiary Composite Total Petroleum System } \\
\hline $\begin{array}{c}\text { Tuscaloosa Marine Shale } \\
\text { Continuous Oil AU }\end{array}$ & 1.0 & Oil & 181 & 1,151 & 4,215 & 1,537 & 529 & 3,406 & 12,742 & 4,614 & 15 & 99 & 393 & 138 \\
\hline $\begin{array}{l}\text { Total undiscovered } \\
\text { continuous resources }\end{array}$ & & & 181 & 1,151 & 4,215 & 1,537 & 529 & 3,406 & 12,742 & 4,614 & 15 & 99 & 393 & 138 \\
\hline
\end{tabular}

\section{References Cited}

Adams, R.L., and Carr, J.P., 2010, Regional depositional systems of the Woodbine, Eagle Ford, and Tuscaloosa of the U.S. Gulf Coast: Gulf Coast Association of Geological Societies Transactions, v. 60, p. 3-27.

Blackwell, D., Richards, M., Frone, Z., Batir, J., Ruzo, A., Dingwall, R., and Williams, M., 2011, Temperature-at-depth maps for the conterminous U.S. and geothermal resource estimates, in Geothermal Resources Council Annual Meeting 2011, San Diego, Calif., October 23-26, 2011: Geothermal Resources Council Transactions, v. 35, p. 1545-1550.

Klett, T.R., Ahlbrandt, T.S., Schmoker, J.W., and Dolton, G.L., 1997, Ranking of the world's oil and gas provinces by known petroleum volumes: U.S. Geological Survey Open-File Report 97-463, 1 CD-ROM, accessed January 18, 2018, at https://pubs.usgs.gov/of/1997/ ofr-97-463/97463.html.
Pitman, J.K., and Rowan, E., 2012, Temperature and petroleum generation history of the Wilcox Formation, Louisiana: U.S. Geological Survey Open-File Report 2012-1046, 51 p., accessed September 1, 2017, at https://pubs.usgs.gov/of/2012/1046.

Rittenour, T.M., Blum, M.D., and Goble, R.J., 2007, Fluvial evolution of the lower Mississippi River valley during the last 100-k.y. glacial cycle - Response to glaciation and sea-level change: Geological Society of America Bulletin, v. 119, p. 586-608.

Wagner, B.E., Sofer, Z., and Claxton, B.L., 1994, Source rock in the Lower Tertiary and Cretaceous deep-water Gulf of Mexico: Gulf Coast Association of Geological Societies Transactions, v. 44, p. 729-736.

Banner image of thin-section photographs of the Tuscaloosa marine shale from Pike County, Mississippi, shows alginite and forams in reflected light (front) and blue-light excitation (back). Photographs by Celeste D. Lohr, U.S. Geological Survey.

\section{Tuscaloosa Marine Shale Assessment Team}

Paul C. Hackley, Catherine B. Enomoto, Brett J. Valentine, William A. Rouse, Celeste D. Lohr, Frank T. Dulong, Javin J. Hatcherian, Sean T. Brennan, William H. Craddock, Thomas M. Finn, Stephanie B. Gaswirth, Phuong A. Le, Heidi M. Leathers-Miller, Kristen R. Marra, Tracey J. Mercier, Stanley T. Paxton, Katherine J. Whidden, Cheryl A. Woodall, and Christopher J. Schenk

\section{For More Information}

Assessment results are also available at the USGS Energy Resources Program website at https://energy.usgs.gov. 